\title{
Van Ryneveld vs Blaine: the UDFI as a civil-military relations football, 1939-1945 ${ }^{1}$
}

\author{
IAN VAN DER WAAG \\ Military History Department, University of Stellenbosch (South African Military \\ Academy)
}

The South African Forces Institute has a unique place not only in the field of military history but also in the province of South African business history. SAFI was a unique organisation established by Lord Roberts, under the designation South African Garrison Institute (SAGI), to fulfil a unique function: to provide the military in South Africa with unified canteen facilities, offering goods and services to troops at reasonable prices. This was aimed specifically at putting an end to the troublesome tradition of those small traders, known as sutlers, who followed armies and exacted extortionate prices from underpaid soldiers for inferior goods.

The Union Defence Force Institute (UDFI), as the organisation was known from 1916 to 1957, performed this task, for the most, quite admirably. It supplied members of the Union Defence Force with canteen facilities in the South West African campaign of the First World War; while the Cape Peninsula (CPGI) and Pretoria Garrison Institutes (PGI), inter-war fragments of the original organisation, served the communities of several garrison towns under the most trying conditions. Throughout the metamorphosis from an essentially civilian-run organisation into a military unit (1968), financial mismanagement coupled to poor business acumen and an extremely pitiable public image were apparent and from an early date. The first inquiry into the affairs of the Institute was held in 1915. This was followed by further inquiries in December 1939, September 1952, February 1961 and January 1966. On practically each occasion insufficient remedial action compounded the situation, making individual employees more brazen. ${ }^{2}$

The lack of remedial action at the highest level in the Union Defence Force, involving no less than the Chief of the General Staff, makes the 1939 investigation and its aftermath most interesting. The rupture between the Chief of the General Staff and the Secretary for Defence, the administrative head of the department, occasioned by this investigation, provides a rare look at South African civil-military relations in this era. However, such negative threads as those under investigation were neither continuous nor ubiquitous. And a grave mistake would be to judge SAFI in view of the "negative overload" in the archival residue of the Institute, which must be ascribed, at least partly, to the chance result of the organisation's particular documentary process.

Unless otherwise indicated, all archival references in this article refer to material in the custody of the Military Archives Depot (Documentation Centre, SANDF), Pretoria. 


\section{Board of inquiry 1939}

From the middle thirties it had become more and more apparent that the Garrison Institutes were not functioning efficiently. Liabilities steadily increased without an increase in trade. This situation drifted throughout the 1930s; and was only brought to halt during the Second World War. A clean up of the UDFI was urgently required as the Union Defence Force required a canteen organisation to supply South African troops in overseas theatres with basic necessities. The civilian financial team at the Defence Secretariat - always wary of their difficult relationship with the uniformed members of the Union Defence Force under the leadership of the vainglorious Chief of the General Staff, Lieutenant General Sir Pierre van Ryneveld would seize the opportunity to vocalise their criticism of the military's management of the institutes.

This was not going to be easy. Van Ryneveld, knighted after his epic flight from London to Cape Town in $1920,{ }^{3}$ completely dominated the war period in South Africa. His unorthodox and autocratic style of centralised command, ${ }^{4}$ for instance, "enabled him to control every aspect of Defence down to the lowest levels ... [h]is forceful personality dominated all about him while his monumental memory for detail enabled him to dictate at levels not usually associated with his exalted position." $\mathrm{He}$ furthermore clearly distinguished between the Union Defence Force and the Department of Defence, and this inevitably placed him in constant collision with the Secretary for Defence. Many colleagues and associates, including the British admiral at Simonstown, experienced similar difficulties when dealing with Van Ryneveld: but then at the time the Royal Navy seemingly had difficulty in dealing with most South Africans. ${ }^{6}$ In consequence, relations between Van Ryneveld and the Secretary for Defence, Brigadier General C.H. Blaine, were never easy and this disrupted the smooth working of the Department; particularly as Van Ryneveld could always fall back on the authority of his mentor, General J.C. Smuts, who was both Prime Minister and Minister of Defence. ${ }^{7}$

The task of exercising supervision over the management committees and drawing the attention of the Minister of Defence to any mismanagement within the UDFI, fell to the Board of Control. ${ }^{8}$ At the request of this body, a Board of Inquiry was appointed by the Secretary for Defence in December 1939, to investigate the activities of the UDFI, and in particular the PGI, and "make representations regarding any changes that may be considered necessary to ensure the achievement of the

3 K. Willers, 'Avontuurlike baanbrekersvlug', Militaria 21(3) 1991, p. 2-5 [The absence of a biography on this remarkable military man, is lamentable.]

4 Public Record Office, London (hereinafter PRO): Dominion Office (hereinafter DO) 119/1110 Defence Union Coastal: Capt Stuart, Senior Naval Officer, Simonstown - Secretary for Defence, Pretoria, 7 Sep 1939.

$5 \quad$ H.J. Martin and N. Orpen, South Africa at war; military and industrial organization and operations in connection with the conduct of the war, 1939-1945 (Cape Town, Johannesburg and London, 1979), p. v.

6 PRO: DO 119/1052 Defence, C.I.D., Union Coastal Defences: memorandum on "South African Coast Defences" attached to V Adm E.R.G.R. Evans - High Commissioner for Basutoland, Bechuanaland Protectorate, and Swaziland, 10 Sep 1935. 
purpose for which Garrison Institutes are authorized." "9 The basic purpose of the UDFI, the cheap and expeditious provision of basic necessities to the serving soldier, was not being done for some time.

After a month of investigation, the three-man commission submitted a report to the Secretary for Defence detailing a number of irregularities. The commission found that the Board of Control did not exercise proper supervision over the management committees enabling the PGI Management Committee to contract overdrafts, on various occasions, without the approval of the Board of Control and without making provisions for the new liabilities. Furthermore, both Garrison Institutes were guilty of making staff changes and additions (a clear indication that nepotism was still taking place) without reference to the Board of Control; and quarterly and annual reports were not being submitted by the general manager or his sectional managers. ${ }^{10}$ The PGI Management Committee was composed entirely of military members, whose service was hampered by frequent transfers and a definite lack of financial experience; and, to worsen matters, the military members on the Board of Control outnumbered the civilians by two to one (the Financial Under Secretary). ${ }^{11}$ The Board of Inquiry's recommendation that the Secretary for Defence, as administrative head of the department, be a member and chairman of the Board of Control and that at least one civilian member, conversant in financial and commercial matters, be appointed to the Management Committee of the PGI - was ignored by the Board of Control. ${ }^{12}$ The military members of the latter body - Van Ryneveld and the Adjutant General, Major General H.S. Wakefield - were clearly unwilling to lose control to the Defence Secretariat, the civilian holders of the Defence Department's purse strings. Brigadier General C.H. Blaine, who became Secretary for Defence in 1939 after being transferred from the Department of Justice, held the ex officio rank of brigadier general in his capacity as the commanding officer of the Essential Services Corps but to all intents and purposes must be classed as a civilian. ${ }^{13}$

This was all anathema to the military members who believed the parlance that an officer could do absolutely anything. The commission further found that the cash position reflected a shortage of liquid resources and a loan of $£ 10000$ was suggested to enable the Institute to settle accounts promptly and thus obtain every possible discount: impatient creditors would also not want to deal with the UDFI in the future. The report also stressed that the object of the PGI was to keep profits at the minimum; and that the management had not done enough to ensure the financial security of the Institutes. The payment of rebates should have been restricted until a strong cash reserve had been created; while all available funds should have been sunk into the repayment of loans. There was a basic problem here. The management did not see

9

Archives of the Secretary for Defence (hereinafter DC), Box 3046, file DC 1423 Committee of Investigation Garrison Institute activities: D. Burke, Secretary, Board of Inquiry - Secretary for Defence, 18 Oct 1941.

10

DC, Box 1897, file DC 247/4 chap 2 Pretoria Garrison Institutes: Report of the Board of Inquiry submitted to the Secretary for Defence, 13 Jan 1940.

11

The post of Financial Under-Secretary appears to have been commensurate with that of Assistant Secretary (Financial) and Chief Paymaster.

Archives of the South African Defence Force Institute (hereinafter SADFI), file B of C 90/1 Investigation 1939 Garrison Institutes; and AG(3), Box 266, file AG(3)2067 vol 1 UDF Institutes Board of Control: précis of the main points in Report of Board of Inquiry, 13 Jan 1940.

Anon., 'General Headquarters', The Nongqai 37(1) Jan 1946, p 56. 
the initial debt of $£ 11767$ to the UDFI Trust Fund as a loan which had to be repaid: it had not been defined as such and no interest was paid thereon. ${ }^{14}$

The physical condition of the premises of the PGI in Voortrekkerhoogte, was also inadequate and the commission suggested that the Department of Defence provide suitable accommodation. The storage of bulk stores was found to be chaotic and it was recommended that a separate bulk store be erected to ensure more effective control: shrinkage would seem to have become a problem. The staff, furthermore, could obtain goods for cash at cost price, plus 5\%. The commission found this to be too beneficial and recommended that all sales to the staff be charged to their account at selling price, less $10 \%$. A coupon or disc system was also recommended for small purchases; and it was suggested that petrol be sold for cash only. ${ }^{15}$

By October 1941, the Board of Control's apathy to the recommendations was indisputable. Few of the recommendations were acted upon and on the more important issues, no action appears to have taken place at all. Of the fourteen key recommendations only four were implemented, two were partly complied with, and eight were completely ignored. The recommendations regarding management and control, were anathema to the military officers; particularly the Chief of the General Staff, Van Ryneveld, who had very definite ideas and was not open to innovative suggestions implying that a military man was not the equal of any civilian.

As a result, the fluctuations in gross profit continued unabated; and the net profit on trading for the PGI over the period ended 1 March 1941, stood at the absurdly low figure of $2,5 \%$. In the opinion of Mr D. Burke, Secretary to the Board of Inquiry, if rent alone was paid by the PGI at regular Pretoria rates, the Institute would not have survived. In view of the apparent reluctance of the Board of Control to assume its supervisory responsibility over the Garrison Institutes, Burke suggested that the Secretary for Defence consider the desirability of sending a report to the Minister of Defence. ${ }^{16}$

In terms of the UDFI constitution, this task fell to the Board of Control and not the Secretary for Defence. ${ }^{17}$ The Defence Legal Adviser accordingly warned Blaine not to get involved with the implementation of the recommendations of the Board of Inquiry, unless the civilian side of the Department of Defence obtained control of the Board of Control and the two Management Committees. ${ }^{18}$ That is, not until the implementation of the recommendation appointing the Secretary for Defence as chairman of the Board of Control, so increasing the civilian element on the board to two members. Should Blaine have facilitated a full implementation of the proposals it would have confirmed, in the minds of the soldiers, the idea that their civilian

14 SADFI, file B of C 90/1 Investigation 1939 Garrison Institutes; and AG(3), Box 266, file AG(3)2067 vol 1 UDF Institutes Board of Control: précis of the main points in Report of Board of Inquiry, 13 Jan 1940.

SADFI, file B of C 90/1 Investigation 1939 Garrison Institutes; and AG(3), Box 266, file AG(3)2067 vol 1 UDF Institutes Board of Control: précis of the main points in Report of Board of Inquiry, 13 Jan 1940. Burke, Secretary, Board of Inquiry - Secretary for Defence, 18 Oct 1941.

17 G.O. 4859 (UDF General Orders No 452 dated 2 May 1923).

DC, Box 3046, file DC 1423 Committee of Investigation Garrison Institute activities: Defence Legal Adviser - Secretary for Defence, 6 Nov 1941. 
colleagues were wanting control of the UDFI and the displacement of the Chief of the General Staff as chairman of the Board of Control.

Following the advice of the Defence Legal Adviser, Blaine referred the matter to the Board of Control, ${ }^{19}$ who simply resolved to "hold over the DC minute for consideration at a later date;" ${ }^{20}$ while the same meeting - in direct opposition to the recommendations - approved rebates of $7 \%$ and $7,5 \%$ on paid customer accounts at the PGI and CPGI respectively: done in an attempt to maintain the goodwill of the customers. After a lapse of two years, the Board merely recorded "that it was too late to examine the report in detail ${ }^{, 21}$ and the report of the Board of Inquiry was shelved with no material action taken on any of the recommendations.

\section{Statutory privilege}

In an attempt to increase profit, the PGI contravened certain of the regulations governing the trading of the Institutes and faced prosecution in 1942. The Board of Control sought a quick-fix and consequently requested the promulgation of a special war measure enabling the Garrison Institutes to trade with civilians - as the UDFI had done in South West Africa during the First World War - and exempt the institutes from the provisions of the Weights and Measures Act, the Shop Hours Ordinance and the Wage Determination Act. This was hardly the same. During the First World War, the UDFI had brought real benefit to the people of South West Africa, who would otherwise had been exploited by one or two traders. The PGI of 1942, on the other hand, was a small, old-fashioned, mismanaged shopping organisation only managing to keep its head above water by the patronage of the all-powerful Chief of the General Staff, who chaired its Board of Control.

It is not surprising that the Board of Control's request did not meet with the support of Defence Secretary Blaine, who believed that the existing privileges enjoyed by the Garrison Institutes, freeing them from the payment of licences, taxes, duties and fees ${ }^{22}$ already placed the Institutes in a position to undersell ordinary civilian establishments. Blaine deemed the extension of these already considerable privileges most unwise as the acts concerned protected the customers and staff ${ }^{23}$ of the Garrison Institutes and any promulgation exempting the Institutes from their effect would not be a good example to non-government institutions. Having decided to oppose the promulgation of the war measure, Blaine found himself - in the words of

19 DC, Box 3046, file DC 1423 Committee of Investigation Garrison Institute activities: Secretary for Defence - Secretary to the Board of Control, 10 Nov 1941 [The original minute was found on SADFI, file B of C 90/1 Investigation 1939 Garrison Institutes.] Institutes Board of Control: minutes of meeting of Board of Control, 5 and 11 Dec 1941 attached to Secretary, Board of Control - Adjutant General, undated.

DC, Box 3046, file DC 1423 Committee of Investigation Garrison Institute activities: Secretary for Defence - Minister of Defence, 14 Jul 1945 [The copy sent to General van Ryneveld may be found in the archives of the Chief of the General Staff, 20/1 Investigation 1939 Garrison Institutes.]

See F.L. Coleman et al, Economic history of South Africa (Pretoria 1983), pp. 29-33; and J. Nattrass, The South African economy; its growth and change (Cape Town, 1981), p. 76. 
http://scientiamilitaria.journals.ac.za

his deputy - in the "slightly awkward (position) to refuse the request made by the Board of Control.", 24

Blaine sought the counsel of the Financial Adviser, E.H. Lewis, who suggested a compromise with the other departments concerned and so avoid the publication of the war measure. ${ }^{25}$ Eventually, after a year of confrontation, an agreement was reached in December 1943. The Board of Control conceded their request for the statutory exemptions in exchange for the legalisation of the civilian trade, limited to certain groups: but as determined by the Board of Control. The draft measure had stipulated that the civilian trade was to be conducted at the discretion of the Secretary for Defence but Blaine had to concede this point too. ${ }^{26}$

\section{Financial position of the PGI 1944-1945}

In 1944, the Pretoria Garrison Institute was on the verge of bankruptcy. The balance sheet for the year ended 26 August 1944 reflected a sundry debtors account of $£ 45558$, of which $£ 20100$ was classed as bad or doubtful debt - something which was not disclosed to the Assistant Secretary Financial at a meeting of the Board of Control on 18 December $1944 .^{27}$ No provision whatsoever was made for the redemption of loans amounting to $£ 28471.1$.1 borrowed from the UDFI Trust Fund and a bank overdraft of $£ 3705$ which had accrued by 26 August 1944, despite net profits for the period March 1939 to August 1944 totalling £81 776. This enormous amount of money was dissipated in excessive rebates to customers and in making donations to War Funds instead of being used to secure the financial stability of the PGI. ${ }^{28}$

The liquid state of the PGI's finances was further aggravated at the end of 1944 by the payment of an annual rebate of $£ 11218$ and the donation of $£ 4500$ to troop welfare organisations. ${ }^{29}$ At the meeting of the Board of Control held on 18 December 1944, R.W. Patterson, the Assistant Secretary (Financial), insisted that his vote against the rebate be recorded. ${ }^{30}$ By August 1945, the PGI had no working

DC, Box 3046, file DC 1423 Committee of Investigation Garrison Institute activities: Menzies Murray, Under Secretary for Defence - Secretary for Defence, 23 Dec 1942.

DC, Box 3046, file DC 1423 Committee of Investigation Garrison Institute activities: E.H. Lewis, Financial Adviser - Secretary for Defence, 29 Dec 1942.

DC, Box 3046, file DC 1423 Committee of Investigation Garrison Institute activities: Under Secretary for Defence - Defence Legal Adviser, Jan 1943; Secretary for Defence - Secretary to the Board of Control, 26 Feb 1943; Secretary to the Board of Control - Secretary for Defence, 22 Dec 1943; and Under Secretary for Defence - Secretary for Defence, undated.

DC, Box 1897, file 247/4 chap 2 Pretoria Garrison Institutes: Assistant Secretary Financial Secretary to the Board of Control, 23 May 1945.

DC, Box 1895, file DC 247/0 Union Defence Force Institutes (Garrison Institutes), General: Assistant Secretary (Financial) - Secretary for Defence, 25 May 1945.

Archives of the Chief of the General Staff (hereinafter CGS), Bundle 20/1 Garrison Institutes: telex Decant (Lt Col T.H. Rowell, Controller of Institutes, Messes and Canteens) Quartermaster General, 3 Apr 1945. 
capital to speak of and was financed at the expense of its creditors - current liabilities exceeding the floating assets to the tune of $£ 4,002.12 .1$. $^{31}$

\section{Fiscal dispute}

During the closing years of the war, a situation developed which sharpened the feeling between the civil and military elements in the Department of Defence, evoked the disgust of a previous member of the Board of Control - E.H. Lewis, who had been Financial Under Secretary in the Department of Defence - and induced the resignation of the Assistant Secretary (Financial) from the Board of Control.

In 1945, the Management Committee of the PGI applied for an additional loan of $£ 10,000$ from the UDFI Trust Fund, so as to provide additional working capital for the payment of the creditors' account: then four months in arrears. ${ }^{32}$ Anticipating the division on the Board of Trustees, the Board of Control advanced the request with a recommendation that only $£ 5000$ be considered for the loan. However, their precaution did not diminish the disparagement of the civilian members on the Board of Trustees. Existing loans to the PGI and the CPGI already amounted to £28 471.1.1 and $£ 2768.14 .3$ respectively, leaving approximately $£ 12000$ in the Trust Fund, of which $£ 5000$ was earmarked as security for the PGI's overdraft. ${ }^{33}$

Patterson was prepared to recommend a loan of five thousand pounds at $4 \%$ interest provided "that the rebate to customers out of the current year's profits after allowing for the usual staff bonus and donations will not exceed $5 \%$ unless the payment of the suppliers accounts is up to date."34 Patterson had also insisted on these conditions when the PGI Management Committee had approached the Board in 1944 for a loan of nine hundred pounds for alterations and improvements to the PGI building at Defence Headquarters, Pretoria. He believed that the PGI, in view of its large profit, should have been able to finance building projects and build up a cash reserve from its own resources - something any similar trading concern would have had to do. ${ }^{35}$ The members of the Board of Trustees generally, though not universally, appear to have been of the opinion that the military management of the Garrison Institutes saw the Trust Fund as an easy way out of a sticky situation. The Board of Trustees comprised five members: the Secretary for Defence (Chairman), the Chief of the General Staff, the Quartermaster General, the Financial Under Secretary in the Department of Defence, and any member of the Council of Defence other than the Minister of Defence or an official or officer of the Department of Defence. This was a conscious balance of interest: two civilian members and two military members. The

31 CGS, Bundle 20/1 Garrison Institutes: Secretary, Board of Control - Chairman, Board of Control, 22 Aug 1945.

DC, Box 1897, file DC 247/4 chap 2 Pretoria Garrison Institutes: Secretary, Board of Control - Hon. Secretary, Board of Trustees, UDFI Trust Fund, 27 Apr 1945.

33 DC, Box 1897, file DC 247/4 chap 2 Pretoria Garrison Institutes: Assistant Secretary (Financial) - Secretary for Defence, the Chief of the General Staff, and the Quartermaster General, 30 April 1945.

DC, Box 1897, file DC 247/4 chap 2 Pretoria Garrison Institutes: Assistant Secretary (Financial) - Secretary for Defence, the Chief of the General Staff, and the Quartermaster General, 30 April 1945.

DC, Box 1897, file DC 247/4 chap 2 Pretoria Garrison Institutes: Secretary for Defence Quartermaster General and the Adjutant General, 21 Jun 1944 [Only one page of the letter is on file.] 
fifth trustee the "non-alione htp: J"scientiamlitaria.journals.ac.za fifh trustee, the "non-aligned" member of the Defence Council, however, normally voted with the civilian element. ${ }^{36}$

Patterson attributed the Institute's growing debt to the custom of disposing of all of the profits in the form of either grants or rebates to customers. E.H. Lewis, summoned before the 1939 Board of Inquiry, too declared that profits ought to have been ploughed back into the business and not distributed exclusively to the benefit of customers. Dissatisfaction had arisen among the men in the Pretoria and Roberts Heights garrisons, who were under the impression that the cost of extra trading facilities were to be met from capital and not from the profits which they had helped generate. This, as Lewis explained to the Board of Inquiry, was an anomaly as the men who complained had little to do with the initial build-up of capital then vested in the UDFI Trust Fund. This money was largely obtained from the members of the Union Defence Forces who had supported the old SAGI during the First World War. ${ }^{37}$

Furthermore, a precedent for distributing all of the profits produced by the UDFI and its predecessor, the SAGI, did not exist. In 1902, Lord Kitchener had ordered the erection of the stone and brick garrison institute building at Roberts Heights from the profit that the SAGI had produced during the Second Anglo-Boer War; and, in 1921, the UDFI Trust Fund was established from the profits the UDFI had made during the First World War. During the first years of the PGI's existence, additional buildings were erected and a dairy and butchery were added to the business of the Institute by virtue of the Management Committee adopting a policy of not distributing all of the profits, but rather using them to extend the business of the Institutes. ${ }^{38}$ Van Ryneveld, on the other hand, maintained that the UDFI Trust Fund was there precisely for the purpose of financing the Garrison Institutes and was even prepared to realise some of the Trust Fund's fixed securities in order to provide the $£ 5$ 000 required by the PGI. ${ }^{39}$

In May 1945, Blaine again solicited Lewis' advice, who - as a former Financial Under-Secretary in the Department of Defence - had served on the UDFI Board of Control and the PGI Management Committee until 1930. ${ }^{40}$ Lewis - who, following his war-induced re-appointment as Financial Adviser in September 1939, disclaimed having anything to do with the UDFI Trust Fund or the PGI - replied in no uncertain terms:

"Personally, if I had anything to do with the PGI, I should be ashamed of putting forward a request for a loan of $£ 5000$ in view of the appalling way the finances of the Institutes have been managed (or, rather, mismanaged) in the past ... It is completely beyond my comprehension how such a state of affairs can be squared in the minds

\footnotetext{
36

See I.J. van der Waag, A History of the South African Defence Force Institute, p 16; and the Deed of Trust of the UDFI Trust Fund embodied in G.O. 4108 (UDF General Orders No 362 dated 17 Aug 1921). DC, Box 1456, untitled file no 70: evidence of E.H.Lewis, the Financial Under-Secretary in the Department of Defence, before the Board of Inquiry, 94th Witness. DC, Box 1456, untitled file no 70: evidence of E.H.Lewis, the Financial Under-Secretary in the Department of Defence, before the Board of Inquiry, 94th Witness. CGS, bundle 20/1 Garrison Institutes: Assistant Secretary (Financial) - Secretary for Defence, the Chief of the General Staff, and the Quartermaster General, 30 Apr 1945. of Control - D. Sloan, 16 May 1930.
} 
of those responsible for the running of the Institute ... In all the circumstances I cannot advise you to agree to the request for a loan of £5 000." ${ }^{41}$

By May 1945, the controversy had gained momentum. In a minute addressed to the Secretary for Defence, Patterson - who was an ex officio member of both the Board of Control and the Board of Trustees - expressed his desire to be relieved of his responsibilities to the UDFI Board of Control:

"It is clear to me that the affairs of the PGI have gone far beyond the stage where they should have been reported to the Minister of Defence by the Board of Control [in terms of GO 4859 of 2 May 1923] and much as I regret adding to your troubles and his at this stage of events I feel I cannot continue to serve on the Board and I shall be glad if you will be good enough to request the Minister of Defence to relieve me of my responsibilities in this connection. ${ }^{, 42}$

Patterson was the only civilian sitting on the Board of Control, where he was continually opposed by the military members of the Board, even concerning financial matters (on which he was the expert), and when it came to a show of hands he was continually outvoted. On at least one occasion information regarding the PGI debtors account was withheld from him, while on another he had insisted that his vote against the allowing of the rebate be recorded in the minutes. Patterson was now the second civilian member of the Department of Defence having financial grounding, to disclaim the want of having anything to do with the UDFI: Lewis had done so in September 1939 on the eve of the Board of Inquiry.

Blaine, now forced to act, informed the members of the Board of Trustees that "in view of the unsatisfactory financial position of the PGI ... [he was] unable to agree to the loan asked for until the affairs of the Institution have been put in order, and the management should be advised to take immediate steps to effect the necessary improvements." 43 Blaine was not authorised to approach the Minister of Defence or the Management Committees directly when dealing with Institute matters. However, in July 1945, at variance with the dilatory behaviour of the Board of Control and contrary to the advice received from the Defence Legal Adviser in 1941, he drafted a minute to the Minister of Defence in which he gave a detailed exposition of the financial problems of the Garrison Institutes and the UDFI Trust Fund. The Secretary blatantly laid "the responsibility for the state of affairs ... with the Board of Control for as regards the granting of rebates to customers and donations out of profits, it appears to have disregarded the recommendations of the Management Committee and also of the auditors and ignored the auditor's recommendations for the increase of reserves and the provision of sufficient working capital." He suggested that "a direction as to the future policy to be followed in the matter of strengthening the cash

\footnotetext{
41 DC, Box 1897, file DC $247 / 4$ chap 2 Pretoria Garrison Institutes: E.H. Lewis, Financial Adviser - Secretary for Defence, 7 May 1945 [Parenthesis is Lewis'.]

42 DC, Box 1895, file DC 247/0 Union Defence Force Institutes (Garrison Institutes), General: Assistant Secretary (Financial) - Secretary for Defence, 25 May 1945.

43 DC, Box 1897, file DC 247/4 chap 2 Pretoria Garrison Institutes: Secretary for Defence Chief of the General Staff and the Quartermaster General, 29 May 1945.
} 
reserves and the treatment of the Trust Fund loans" be clearly indicated by the Minister of Defence, General J.C. Smuts. ${ }^{44}$

It would appear as if Blaine, who was now ultra vires, did not actually send this minute to the Minister of Defence - the file copy is unsigned and undated - but rather used it to elicit a response from Van Ryneveld. Similarly, it would seem as if he was not prepared to interfere in the relationship between Smuts and Van Ryneveld: a relationship described by the official historians of the Second World War, as being "an almost David and Jonathan association." 45 In consequence, Blaine sent a copy of his draft minute to Van Ryneveld for comment only.

After seven weeks and one reminder, Van Ryneveld informed Blaine that "some of [Blaine's] proposed statements and deductions are so wide of the mark, I do not think that your minute will achieve anything other than wasting the PM's [Prime Minister's] time and if you still wish to pursue the matter that you take an opportunity of meeting the Board of Control.,46 Blaine apparently did not accept Van Ryneveld's invitation to meet the Board. His criticisms, described by Van Ryneveld as "so wide of the mark," were based on reports submitted by responsible officials, one being the Assistant Secretary (Financial), the civilian member of the Board of Control. Blaine, no doubt, saw such a meeting as counterprojuctive and unnecessary, and no evidence could be found to establish whether it ever took place or not. ${ }^{47}$

Blaine retired on 31 December 1945. Although the recommendations of his board of inquiry were not fully, or even partly, implemented, his dispute with the Chief of the General Staff appears to have borne some fruit. No rebates were paid for the financial year ending 25 August $1945 .{ }^{48}$ By December, creditors' accounts were paid up to the end of September and $£ 1,320$ was paid off the overdraft. Bad and doubtful debts diminished from $£ 20100$ in 1944 to $£ 9,200$ by the end of $1945{ }^{49}$

Although the conflict between the Secretary for Defence and the Chief of the General Staff between 1939 and 1945, appears to have introduced a certain amount of financial dexterity, it by no means meant that the civilian and military members of the Department of Defence had reached a sound, working relationship as regards the running of the Institutes. In fact, the UDFI remained a point of friction until at least 1955 when a "more understanding" man, in the person of J.P. de Villiers, was appointed Secretary for Defence. ${ }^{50}$ A former general manager of the South African Defence Force Institute (1968-1976), Brigadier L.B. Hopkins, has suggested that the primary reason behind the friction on the issue of the UDFI, was the inability of the

DC, Box 3046, file DC 1423 Committee of Investigation Garrison Institute activities: Secretary for Defence - Minister of Defence, undated.

H.J. Martin and N. Orpen, South Africa at war; military and industrial organization and operations in connection with the conduct of the war, 1939-1945, p. vi.

DC, Box 3046, file DC 1423 Committee of Investigation Garrison Institute activities: Chief of the General Staff - Secretary for Defence, 3 Sep 1945.

CGS, bundle 20/1 Investigation 1939 Garrison Institutes: Secretary for Defence - Chief of the General Staff, 29 Sep 1945 and 8 Nov 1945.

DC, Box 3046, file DC 1423 Committee of Investigation Garrison Institute activities: Secretary, PGI Management Committee - All units in the Voortrekkerhoogte and Pretoria areas, 20 Dec 1945. Assistant Secretary (Financial) - Secretary for Defence, 13 Dec 1945.

Personal information: Brig L.B. Hopkins, East London, 13 Mar 1989. 
members of the Defence Secretariat to reconcile themselves with the fact that they, as civilian members of the department, were not permitted to share in the benefits offered by the Institutes to their military counterparts. ${ }^{51}$ This seems something of an oversimplification.

Lieutenant General Sir Pierre van Ryneveld's autocratic control and inability to delegate, coupled to the vetoing of individual initiative, inevitably led to the making of ill-considered management decisions: perhaps few more ill-considered than those relating to the Pretoria Garrison Institutes. According to the official historians, Van Ryneveld did not learn good-management lessons of any kind during the war and continued his unique leadership and management style in the post-war Union Defence Force until unseated, for political reasons, by the National Party government. ${ }^{52}$

$51 \quad$ Personal information: Brig L.B. Hopkins, East London, 13 Mar 1989.

52 H.J. Martin and N. Orpen, South Africa at war; military and industrial organization and operations in connection with the conduct of the war, 1939-1945, pp. v-vi. 